\title{
PENGEMBANGAN MEDIA PEMBELAJARAN INTERAKTIF IPA BERBASIS MODEL PEMBELAJARAN GUIDED INQUIRY PADA MATERI GAYA DI KELAS IV SD NEGERI 101776 SAMPALI
}

\author{
Nurul Annisa, Naeklan Simbolon \\ Surel: nurulnisa125@gmail.com
}

\begin{abstract}
ABSTRAK
Penelitian ini bertujuan untuk: (1) mengetahui kelayakan media pembelajaran interaktif berbasis model pembelajaran Guided Inquiry pada materi Gaya di kelas IV SD Negeri 101776 Sampali dan (2) mengetahui keefektifan penggunaan media interaktif berbasis model pembelajaran Guided Inquiry pada materi Gaya di kelas IV SD Negeri 101776 Sampali T.A 2017/2018. Jenis penelitian ini adalah penelitian pengembangan yang menggunakan model pengembangan produk Borg dan Gall yang dipadukan dengan model pengembangan Dick dan Carey. Subyek uji coba terdiri dari 3 siswa untuk uji perorangan, 9 siswa untuk uji kelompok kecil, dan 29 siswa untuk uji lapangan terbatas. Berdasarkan hasil uji hipotesis menggunakan uji t dengan taraf signifikansi $(\alpha=0,05)$ diperoleh thitung sebesar 2,76 dan tabel 2,001. Dari hasil ini, diketahui bahwa thitung $\geq$ tabel menunjukkan terdapat perbedaan hasil belajar antara siswa yang menggunakan media pembelajaran interaktif berbasis model pembelajaran guided inquiry (inkuiri terbimbing) dengan siswa yang menggunakan model pembelajaran guided inquiry (inkuiri terbimbing) dan buku teks.
\end{abstract}

Kata kunci: Development Of Interactive Learning Media, IPA, Model Pembelajaran Guided Inquiry

\begin{abstract}
This study aims to: (1) find out the feasibility of interactive learning media based on learning model Guided Inquiry on Style material in class IV SD Negeri 101776 Sampali and (2) to know the effectiveness of using interactive media based on learning modelGuided Inquiry on the material of Style in class IV SD Negeri 101776 Sampali FY 2017/2018. This type of research is a development research using the Borg and Gall product development model combined with the Dick and Carey development model. Trial subjects consisted of 3 students for individual testing, 9 students for small group testing, and 29 students for limited field testing. Based on hypothesis test result using t test with significance level $(\alpha=0,05)$ obtained titung 2,76 and ttabel 2,001. From these results, it is known that thitung $\geq \mathrm{t}$ table shows there are differences in learning outcomes between students using interactive learning media based on guided inquiry model (guided inquiry) with students using guided inquiry model (guided inquiry) and textbooks.
\end{abstract}

Keywords: Development Of Interactive Learning Media, IPA, Model Guided Inquiry. 
Nurul Annisa, Naeklan Simbolon: Pengembangan Media...

\section{PENDAHULUAN}

Dalam era globalisasi, perkembangan teknologi memberikan pengaruh terhadap kemajuan dunia pendidikan. Inovasiinovasi baru dalam ilmu pengetahuan lahir seiring dengan berkembangnya teknologi. Hal ini sejalan dengan pendapat Simbolon (2017:1) yang menyatakan "globalisation process continues in accordance with the

development of science and technology". Pengaruh globalisasi tidak hanya berdampak terhadap ilmu pengetahuan dan teknologi saja, tetapi juga berdampak pada karakteristik maupun gaya belajar generasi yang ada saat ini. Anakanak yang sedang menempuh pendidikan di tingkat SD, SMP, dan SMA tahun 2018 saat ini termasuk kedalam kelompok generasi $\mathrm{Z}$.

Generasi $\mathrm{Z}$ atau biasa disebut dengan Generasi Net atau Generasi Internet adalah generasi yang lahir pada tahun 1995-2010 dan terlahir dari generasi $\mathrm{X}$ dan generasi $\mathrm{Y}$. Menurut Howe (2007:41-52) dalam artikelnya "The Next 20 Years: How Customer and Workforce Attitude Will Evolve" menyatakan bahwa dalam teori generasi (Generation Theory) hingga saat ini dikenal ada 5 generasi, yaitu: 1) Generasi Baby Boomer (lahir 1946-1964), 2) Generasi X (lahir 1965-1980), 3) Generasi Y (lahir 1981-1994), Generasi Z (lahir 1995-2010) dan Generasi Alpha (lahir 2011-2025). Berbeda dengan generasi-generasi pendahulunya, generasi $\mathrm{Z}$ memiliki kemampuan yang lebih baik di bidang teknologi. Helen Chou P. (2012:35) menyatakan bahwa "Generasi $\mathrm{Z}$ atau yang kemudian banyak dikenal dengan generasi digital merupakan generasi muda yang tumbuh dan berkembang dengan sebuah ketergantungan yang besar pada teknologi digital".

Pembelajaran adalah proses interaksi antara peserta didik dengan pendidik dan sumber belajar pada

suatu lingkungan belajar (Mendikbud, 2014). Pembelajaran di sekolah dapat terlaksana dengan baik apabila penyampaian guru dari sumber belajar dapat memberikan pemahaman kepada siswa dengan baik. Pemilihan metode dan media pembelajaran yang digunakan sebagai sarana dalam menyampaikan materi pelajaran kepada siswa juga turut berpengaruh terhadap keefektifan proses belajar. Penggunaan metode dan media pembelajaran yang tepat akan dapat menghindarkan siswa dari rasa kantuk dan bosan, terlebih untuk mata pelajaran yang memiliki banyak materi bersifat abstrak seperti materi Ilmu Pengetahuan Alam (IPA).

Pembelajaran IPA bagi siswa di sekolah dasar mendorong siswa untuk memupuk rasa ingin tahu secara alamiah. IPA melatih siswa untuk berpikir kritis dan objektif serta membantu siswa untuk belajar memecahkan masalah yang berkaitan dengan kehidupannya seharihari.Siswa baru mampu berfikir secara sistematis dalam proses pembelajaran IPA apabila dalam 
pembelajaran menggunakan bendabenda yang konkret atau proses pembelajaran diajarkan melalui kegiatan percobaan yang dapat memberikan pengalaman langsung bagi siswa. Dengan kata lain siswa memerlukan suatu media untuk untuk memahami materi pelajaran IPA.

Namun kenyataannya, berdasarkan hasil wawancara yang dilakukan dengan guru kelas IV SD Negeri 101776 Sampali, diperoleh informasi bahwa mata pelajaran IPA merupakan mata pelajaran yang sangat sulit untuk dipahami siswa. Berdasarkan hasil observasi di lapangan dan hasil wawancara dengan guru kelas IV diketahui bahwa beberapa faktor yang menjadi permasalahan dalam proses pembelajaran IPA diantaranya adalah penggunaan metode pembelajaran yang kurang bervariasi menyebabkan kurangnya keaktifan siswa dalam belajar IPA. Guru merasa kesulitan menentukan model atau metode pembelajaran yang tepat untuk

digunakan dalam proses pembelajaran, sehingga lebih banyak menggunakan metode ceramah. Secara umum proses pembelajaran berjalan dengan baik, namun ketika guru menjelaskan materi IPA dengan metode konvensional, siswa kurang memiliki gambaran nyata tentang bagaimana benda, proses atau suatu hal tersebut dapat terjadi. Hal ini menyebabkan siswa menjadi lebih pasif dan mudah bosan serta minat belajar siswa untuk belajar IPA menurun dikarenakan siswa hanya mendengarkan penjelasan materi dan menerimanya begitu saja dari guru.

Selain itu, faktor lainnya ialah kurangnya keterampilan guru dalam membuat media pembelajaran yang efektif dan kurangnya penggunaan media pembelajaran dalam proses pembelajaran.Meskipun kelas IV di SD Negeri 101776 Sampali telah menerapkan kurikulum 2013 dalam proses pembelajarannya, akan tetapi penggunaan media pembelajaran yang dapat membuat siswa aktif masih jarang digunakan. Berdasarkan hasil wawancara yang telah dilakukan dengan guru kelas IV SD Negeri 101776 Sampali, guru lebih sering menggunakan media gambar yang ada di buku. Guru

menyatakan tidak pernah menggunakan media lain selain media gambar ataupun media berbasis komputer dikarenakan kurangnya fasilitas dan keterampilan guru dalam menggunakannya meskipun guru telah mengenal media berbasis komputer seperti media Powerpoint.

Berdasarkan permasalahan di atas, maka dari itu diperlukan adanya suatu pembaharuan dalam proses pembelajaran agar siswa dapat dengan mudah memahami materi pelajaran IPA. Salah satu caranya yaitu dengan mengembangkan media pembelajaran interaktif yaitu Powerpoint dan dipadukan dengan model pembelajaran yang dapat membuat siswa menjadi aktif, yaitu model pembelajaran inkuiri terbimbing (Guided Inquiry). 
Nurul Annisa, Naeklan Simbolon: Pengembangan Media...

Tujuan penelitian pengembangan ini adalah:

a. Mengembangkan media pembelajaran interaktif IPA berbasis model pembelajaran Guided Inquiry yang layak digunakan untuk siswa kelas IV SD Negeri 101776 Sampali Tahun Ajaran 2017/2018.

b. Mengetahui keefektifan penggunaan media pembelajaran interaktif IPA berbasis modelpembelajaranGuided

Inquiry untuk siswa kelas IV SD Negeri 101776 Sampali Tahun Ajaran 2017/2018.

\section{METODE PENELITIAN}

Penelitian ini merupakan jenis Penelitian Pengembangan (Development \& Research) yang menggunakan model pengembangan menurut Borg and Gall dipadukan

dengan model pengembangan pembelajaran Dick \& Carey. Dalam penelitian ini, produk yang akan

dikembangkan adalah media pembelajaran menggunakan software powerpoint dan i-spring. Penelitian pengembangan ini difokuskan pada pengembangan media pembelajaran interaktif Ilmu Pengetahuan Alam (IPA) pada materi gaya berbasis model pembelajaran Guided Inquiry (Inkuiri Terbimbing) di kelas IV SD/MI.

Penelitian ini dilaksanakan di SD Negeri 101776 Sampali yang terletak di J1. Irian Barat Pasar VII Desa Sampali, tepatnya pada siswa kelas IV SD semester genap tahun ajaran 2017/2018. Waktu pelaksanaan penelitian ini dimulai dari bulan Januari sampai dengan bulan Mei 2018. Adapun prosedur pengembangan yang ditempuh untuk menghasilkan media pembelajaran interaktif IPA ini di bagi menjadi 5 tahap, yaitu: a) melakukan penelitian terlebih dahulu, b) tahap kedua pembuatan desain produk, c) tahap ketiga pengumpulan bahan, d) tahap keempat yaitu membuat dan memproduksi media pembelajaran interaktif, e) tahap kelima yaitu review atau uji lapangan dalam rangka evaluasi formatif dan revisi produk.

Produk pengembangan media pembelajaran interaktif memerlukan masukan-masukan dalam rangka evaluasi formatif. Masukan-masukan tersebut diperoleh dari para subjek yang terdiri dari ahli desain pembelajaran, ahli materi, ahli media dan pemakai produk yaitu siswa kelas IV SD Negeri 101776 Sampali. Data yang terkumpul dari hasil uji coba produk digunakan sebagai dasar dalam menetapkan kelayakan dan daya tarik terhadap produk yang dikembangkan sebelum dipakai di lapangan.Maka jenis data yang dikumpulkan dalam pengembangan ini adalah data kuantitatif sebagai data pokok, yang terkumpul melalui angket. Para responden akan memberikan angka penilaian pada setiap butir angket berdasarkan kriteria yang telah ditetapkan. Selain itu, jenis data yang dikumpulkan adalah data kualitatif berupa uraian saran dan masukan tertulis oleh responden sebagai data tambahan. 
Instrumen yang digunakan dalam penelitian ini adalah: a) lembar angket untuk analisis kebutuhan, b) lembar angket untuk ahli materi, c) lembar angket untuk ahli desain pembelajaran, d) lembar angket untuk ahli media, e) lembar angket untuk peserta didik, f) lembar wawancara dipakai sebagai alat pegumpul data dari ahli materi baik berupa saran, kritik, dan masukanmasukan, wawancara dengan wali kelas IV serta peserta didik pada saat uji coba perorangan, kelompok kecil dan uji coba lapangan dan tes hasil belajar IPA.

\section{HASIL PENELITIAN DAN PEMBAHASAN}

Proses pengembangan media pembelajaran interaktif ini dilakukan secara bertahap. Tahap pertama dalam kegiatan pengembangan media pembelajaran ini dilakukan

dengan melakukan analisis kebutuhan di SD Negeri 101776 Sampali, yaitu dengan menebar angket kepada 2 guru dan 30 siswa

untuk mengetahui gambaran pengetahuan responden tentang media pembelajaran interaktif serta dengan melakukan wawancara kepada guru kelas IV SD Negeri 101776 Sampali. Penebaran angket terhadap 30 siswa, dilakukan dengan bimbingan dan dinarasikan agar siswa dapat memahami isi angket.

Berdasarkan hasil penelusuran dari angket yang disebar, ditemukan bahwa 90,62\% guru dan siswa menyatakan membutuhkan media pembelajaran interaktif dalam proses pembelajaran agar dapat berjalan lebih efektif.

Berdasarkan hasil analisis kebutuhan yang telah dilakukan, dapat disimpulkan bahwa pengembangan media pembelajaran interaktif memang sangat dibutuhkan oleh guru dan siswa di dalam proses pembelajaran. Melalui hasil wawancara yang dilakukan dengan guru kelas IV ${ }^{\mathrm{B}}$ SD Negeri 101776 Sampali diketahui bahwa guru membutuhkan media pembelajaran interaktif untuk mendukung kegiatan pembelajaran, agar proses belajar menjadi lebih efektif dan menyenangkan serta memudahkan guru dalam menyampaikan materi kepada siswa.

Uji coba media pembelajaran interaktif ini dilakukan dalam 4 tahap, yaitu: (1) evaluasi media oleh ahli materi, ahli desain pembelajaran dan ahli media (rekayasa perangkat lunak), (2) uji coba perorangan, (3) uji coba kelompok kecil, dan (4) uji coba lapangan.

Validasi oleh ahli materi terhadap pengembangan media pembelajaran interaktif pada pembelajaran tematik materi Gaya dilakukan oleh dosen Program Studi Pendidikan Guru Sekolah Dasar (PGSD) yaitu Ibu Lala Jelita Ananda, S.Pd., M.Pd. Hasil validasi ahli materi terhadap pembelajaran media pembelajaran interaktifdari kedua aspek yaitu muatan materi dan penyajian materi pada media pembelajaran interaktif secara keseluruhan menunjukkan bahwa 
Nurul Annisa, Naeklan Simbolon: Pengembangan Media...

media pembelajaran interaktif dinyatakan "Sangat Baik” (92,58\%).

Tabel 1. Tingkat Kecenderungan

Penilaian Ahli Materi Terhadap Media Pembelajaran Interaktif IPA Kelas IV SD/MI

\begin{tabular}{llcc}
\hline No. & Aspek & $\begin{array}{c}\text { Rata- } \\
\text { rata } \\
\text { Skor }\end{array}$ & Kriteria \\
\hline 1. & $\begin{array}{l}\text { Muatan } \\
\text { materi } \\
\text { media } \\
\text { interaktif }\end{array}$ & $92,31 \%$ & $\begin{array}{c}\text { Sangat } \\
\text { Baik }\end{array}$ \\
2. & & \\
& $\begin{array}{l}\text { Penyajian } \\
\text { materi } \\
\text { Rata-rata }\end{array}$ & $92,85 \%$ & $\begin{array}{c}\text { Sangat } \\
\text { Baik } \\
\end{array}$ \\
\end{tabular}

Komentar validator ahli materi tentang muatan materi dan penyajian materi pada media interaktif secara umum dinilai sangat baik, namun ada beberapa saran yang disampaikan yang tercantum dalam tabel 2 berikut ini.

Tabel 2. Rangkuman Saran/Komentar Ahli Materi Terhadap Media Pembelajaran Interaktif IPA

\begin{tabular}{|c|c|}
\hline Indikator Penilaian & $\begin{array}{l}\text { Masalah } \\
\text { saran } \\
\text { direvisi }\end{array}$ \\
\hline $\begin{array}{l}\text { Kemenarikan materi } \\
\text { dalam membantu } \\
\text { pemahaman pengguna }\end{array}$ & $\begin{array}{lr}\text { Diperibaiki, } & \\
\text { dibuat } & \text { lebih } \\
\text { menarik } & \text { dan } \\
\text { variatif. } & \\
\end{array}$ \\
\hline $\begin{array}{lr}\text { Kesesuaian } & \text { bahasa } \\
\text { yang } & \text { digunakan } \\
\text { dengan EBI } & \text { (Ejaan } \\
\text { Bahasa Indonesia) }\end{array}$ & $\begin{array}{lr}\text { Gunakan } & \text { bahasa } \\
\text { yang baku } & \text { dan } \\
\text { perbaiki } & \\
\text { penggunaan } & \text { kata } \\
\text { "kalian" menjadi } \\
\text { "kamu". }\end{array}$ \\
\hline
\end{tabular}

Validasi ahli media atau rekayasa perangkat lunak dilakukan oleh Bapak Adi Widarma, S.Si., M.Kom yang merupakan staff IT Universitas Negeri Medan. Ahli media memberikan penilaian produk pada aspek tampilan dan pemrograman media pembelajaran interaktif. Penilaian media pembelajaran interaktif oleh ahli media terhadap kedua aspek yaitu aspek tampilan dan pemrograman dinilai "Sangat Baik" secara

keseluruhan dengan persentase masing-masing sebesar $92,50 \%$ dan $92,85 \%$.

Tabel 3. Tingkat Kecenderungan Penilaian Ahli Media Terhadap Media Pembelajaran Interaktif IPA Kelas IV SD/MI

\begin{tabular}{llcc}
\hline No. & Aspek & $\begin{array}{c}\text { Rata- } \\
\text { rata } \\
\text { Skor }\end{array}$ & Kriteria \\
\hline 1. & Tampilan & $92,5 \%$ & $\begin{array}{c}\text { Sangat } \\
\text { Baik }\end{array}$ \\
2. & Pemrograman & $94,44 \%$ & $\begin{array}{c}\text { Sangat } \\
\text { Baik } \\
\end{array}$ \\
& Rata-rata & $\mathbf{9 3 , 4 \%}$ & $\begin{array}{c}\text { Sangat } \\
\text { Baik }\end{array}$ \\
\hline
\end{tabular}

Hasil validasi dari ahli media dianalisis sebagai dasar revisi untuk memperbaiki desain media pembelajaran interaktif Ilmu Pengetahuan Alam. Secara keseluruhan penilaian media pembelajaran interaktif dinyatakan "Sangat Baik" (93,4\%) namun perlu beberapa perbaikan. Berikut saransaran yang disampaikan oleh validator ahli media yang tertera pada tabel 4 berikut: 
Tabel 4. Rangkuman

Saran/Komentar Ahli Media

Terhadap Media Pembelajaran Interaktif IPA

\begin{tabular}{|l|l|}
\hline \multicolumn{1}{|c|}{$\begin{array}{c}\text { Indikator } \\
\text { Penilaian }\end{array}$} & $\begin{array}{l}\text { Masalah dan } \\
\text { saran untuk } \\
\text { direvisi }\end{array}$ \\
\hline $\begin{array}{l}\text { Penyajian } \\
\text { tolak ukur } \\
\text { keberhasilan } \\
\text { pembelajaran }\end{array}$ & $\begin{array}{l}\text { Penyajian soal tes } \\
\text { perlu diperbaiki, } \\
\text { karena masih bisa } \\
\text { melihat soal } \\
\text { selanjutnya, } \\
\text { ketika } \\
\text { sebelumnya } \\
\text { belum dijawab. }\end{array}$ \\
\hline $\begin{array}{l}\text { Kejelasan } \\
\text { musik }\end{array}$ & $\begin{array}{l}\text { Diperbaiki agar } \\
\text { lebih jelas dan } \\
\text { tidak kepotong }\end{array}$ \\
\hline
\end{tabular}

Validasi ahli desain pembelajaran dilakukan oleh wali kelas IV $^{\mathrm{B}}$ SD Negeri 101776 Sampali yaitu Ibu Agustina Uli, S.Pd. Ahli desain pembelajaran memvalidasi produk media pada

aspek-aspek

pembelajaran diantaranya yaitu aspek media, penyajian materi dan pembelajaran.

Hasil penilaian ahli desain pembelajaran terhadap media pembelajaran interaktif IPA secara keseluruhan dinilai "Sangat Baik" $(95,13 \%)$. Penilaian ahli desain pembelajaran dapat dilihat pada gambar 4.3 berikut ini.

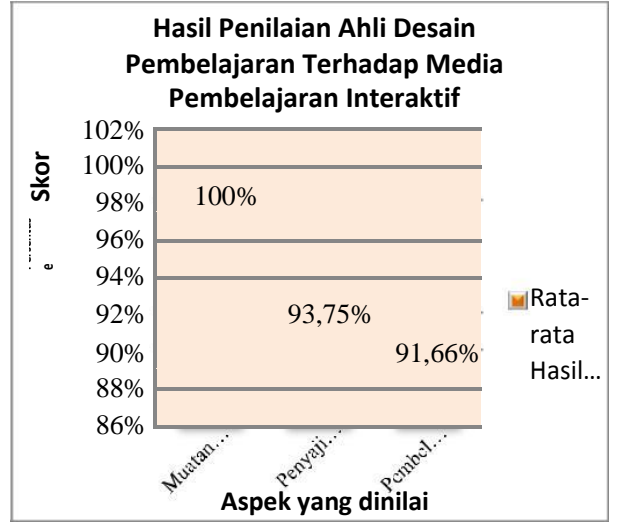

Gambar 1. Perolehan Skor Media Pembelajaran Interaktif IImu Pengetahuan Alam Oleh Ahli Desain Pembelajaran

Berdasarkan hasil validasi oleh validator terhadap media pembelajaran interaktif, maka dilakukanlah beberapa revisi. Adapun revisi yang dilakukan diantaranya sebagai berikut:

a. Masukan oleh ahli materi :

- Kemenarikan materi dibuat lebih menarik dan variatif.

Sebelum revisi

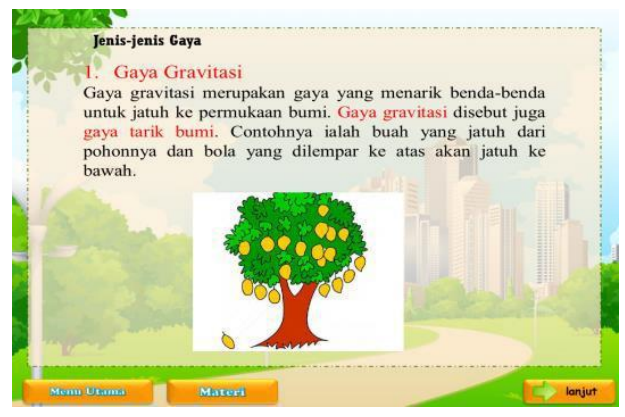

Setelah revisi

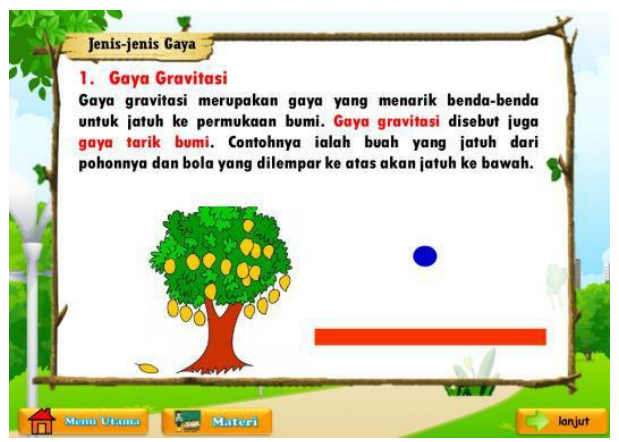


Nurul Annisa, Naeklan Simbolon: Pengembangan Media...

- Gunakan bahasa yang baku dan perbaiki penggunaan kata "kalian" menjadi "kamu".

Sebelum revisi

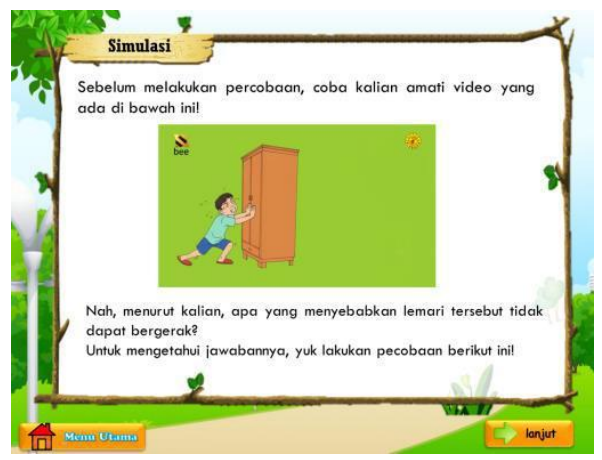

Sesudah revisi

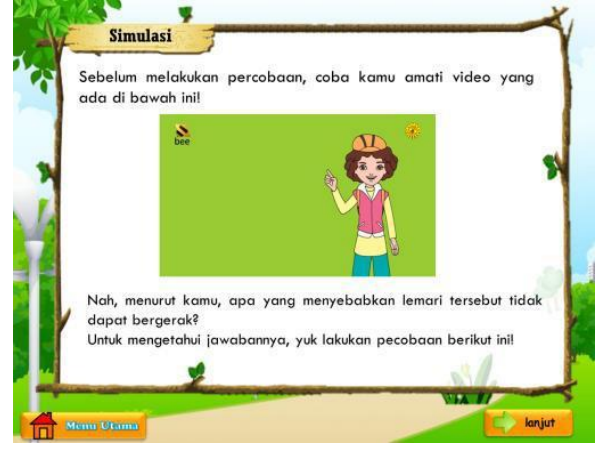

b. Masukan oleh ahli media :

- Penyajian soal tes perlu diperbaiki, karena masih

bisa melihat soal selanjutnya, ketika soal sebelumnya belum dijawab.

Sebelum revisi

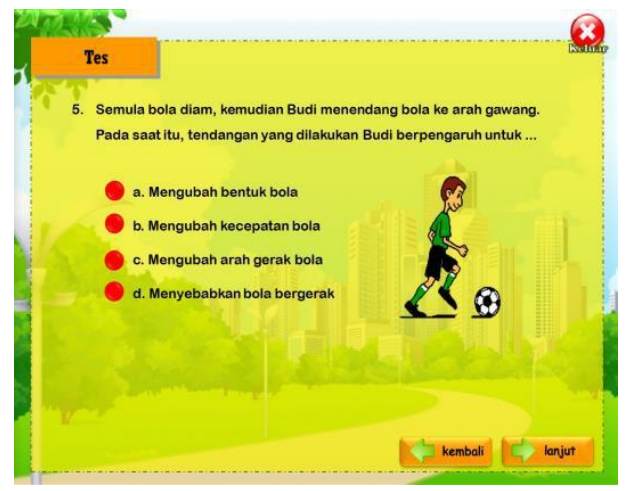

Sesudah revisi

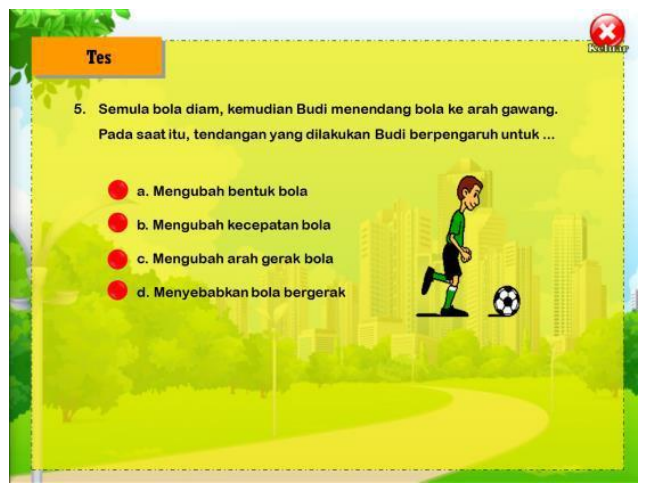

Uji coba perorangan dilakukan pada 3 siswa kelas IV $^{\mathrm{B}}$ SD Negeri 101776 Sampali yang terdiri dari 1 siswa yang memiliki prestasi tinggi, 1 orang yang berprestasi sedang dan 1 orang yang berprestasi rendah. Tujuan dari uji coba perorangan ini ialah untuk mengidentifikasi kekurangan produk media pembelajaran setelah di evaluasi oleh tenaga ahli. Penilaian dan masukan dari uji coba ini adalah tentang penyajian produk pembelajaran meliputi aspek kualitas materi pembelajaran dan tampilan yang terdapat pada media pembelajaran interaktif Ilmu Pengetahuan Alam.

Tabel 5. Tingkat Kecenderungan Penilaian Siswa Pada Uji Perorangan Terhadap Media Pembelajaran Interaktif IPA

\begin{tabular}{|c|c|c|c|}
\hline No. & Aspek & $\begin{array}{l}\text { Rata- } \\
\text { rata } \\
\text { Skor }\end{array}$ & Kriteria \\
\hline 1. & $\begin{array}{l}\text { Kualitas } \\
\text { materi } \\
\text { pembelajaran }\end{array}$ & $93,74 \%$ & $\begin{array}{c}\text { Sangat } \\
\text { Baik }\end{array}$ \\
\hline 2. & $\begin{array}{l}\text { Kualitas } \\
\text { tampilan }\end{array}$ & $89,57 \%$ & $\begin{array}{c}\text { Sangat } \\
\text { Baik }\end{array}$ \\
\hline \multicolumn{2}{|c|}{ Rata-rata } & $91,65 \%$ & $\begin{array}{c}\text { Sangat } \\
\text { Baik }\end{array}$ \\
\hline
\end{tabular}


Berdasarkan data pada tabel 5, pada kegiatan uji coba perorangan yang dilakukan pada 3 orang siswa menunjukkan bahwa hasil tanggapan dari ketiga siswa terhadap aspek kualitas materi pembelajaran dan tampilan media pembelajaran interaktif dinyatakan dalam kriteria "Sangat Baik" $(91,65 \%)$. Pada kegiatan uji coba ini, tidak terdapat masalah yang perlu direvisi pada produk media pembelajaran interaktif. Oleh karena itu kegiatan pengembangan ini dilanjutkan pada uji coba kelompok kecil tanpa ada perbaikan pada tahap II.

Uji coba kelompok kecil juga dilakukan di SD Negeri 101776 Sampali. Uji coba kelompok kecil dilakukan terhadap 9 orang siswa yang terdiri dari 3 siswa yang berprestasi tinggi, 3 siswa yang berprestasi sedang dan 3 siswa yang berprestasi rendah. Data uji coba kelompok kecil ini dimaksudkan untuk mengetahui beberapa kelemahan atau hambatan yang dihadapi ketika produk media interaktif diujicobakan.Penilaian media pembelajaran interaktif pada aspek kualitas tampilan untuk uji coba kelompok kecil di SD Negeri 101776 sampali yang menunjukkan bahwa secara keseluruhan dinilai dalam kategori "Sangat Baik" dengan persentase sebesar 90,27\% . Hasil penilaian uji coba kelompok kecil terhadap kualitas media pembelajaran interaktif IPA dirangkum pada tabel 6 berikut ini.
Tabel 6. Tingkat Kecenderungan

Penilaian Siswa Pada Uji Coba

Kelompok Kecil Terhadap Media

Pembelajaran Interaktif IPA

\begin{tabular}{|c|c|c|c|}
\hline No. & Aspek & $\begin{array}{l}\text { Rata- } \\
\text { rata } \\
\text { Skor }\end{array}$ & Kriteria \\
\hline 1. & $\begin{array}{l}\text { Kualitas materi } \\
\text { pembelajaran }\end{array}$ & $91,66 \%$ & $\begin{array}{l}\text { Sangat } \\
\text { Baik }\end{array}$ \\
\hline 2. & $\begin{array}{l}\text { Kualitas } \\
\text { tampilan }\end{array}$ & $90,27 \%$ & $\begin{array}{l}\text { Sangat } \\
\text { Baik }\end{array}$ \\
\hline \multicolumn{2}{|c|}{ Rata-rata } & $90,96 \%$ & $\begin{array}{l}\text { Sangat } \\
\text { Baik }\end{array}$ \\
\hline
\end{tabular}

Uji coba lapangan dilakukan di SD Negeri 101776 Sampali terhadap siswa kelas IV $^{\mathrm{B}}$ SD Negeri 101776 Sampali yang terdiri dari 29 siswa. Uji coba lapangan menghasilkan data-data yang nantinya dapat mengukur kelayakan dari produk yang dikembangkan serta untuk mengetahui bagaimana manfaat produk tersebut bagi

pemakainya. Penilaian media pembelajaran interaktif pada aspek kualitas tampilan untuk uji coba lapangan di SD Negeri 101776 sampali yang tampak pada tabel 4.23 menunjukkan bahwa secara keseluruhan dinilai dalam kategori "Sangat Baik" dengan persentase sebesar 98,05\%. Dengan demikian, tidak diadakan revisi IV pada tahap uji coba lapangan. Dan hal ini juga berarti media pembelajaran interaktif yang dikembangkan sangat baik atau layak digunakan dan siap diuji keefektifannya.

Uji coba lapangan dilakukan di SD Negeri 101776 Sampali terhadap siswa SD Negeri 101776 Sampali dengan kelas IV ${ }^{\mathrm{B}}$ yang 
Nurul Annisa, Naeklan Simbolon: Pengembangan Media...

terdiri dari 29 siswa sebagai kelas eksperimen dan kelas IV $^{\mathrm{A}}$ yang terdiri dari 32 siswa sebagai kelas

kontrol. Uji coba lapangan menghasilkan data yang diukur dari manfaat atau efektifitas produk dari hasil belajar siswa kelas IV SD Negeri 101776 Sampali. Langkah awal yang dilakukan terhadap kedua kelas sampel sebelum diberikan perlakuan yang berbeda adalah dengan memberikan tes awal kepada siswa untuk mengetahui kemampuan awal masing-masing siswa pada kedua kelas. Kemudian pada langkah selanjutnya, dilakukan pembelajaran yang berbeda yaitu kelas eksperimen diajarkan dengan media pembelajaran interaktif powerpoint menggunakan model pembelajaran Guided Inquiry (Inkuiri Terbimbing) dan kelas kontrol diajarkan dengan model pembelajaran Guided Inquiry (Inkuiri Terbimbing) dan menggunakan buku teks.Kemudian, pada akhir proses pembelajaran akan diberikan tes akhir untuk mengetahui hasil belajar siswa setelah diberikan perlakuan yang berbeda.

Tabel 7. Data Hasil Pretes dan Postes

\begin{tabular}{lllll}
\hline Statistik & \multicolumn{2}{l}{ Kelas } & \multicolumn{3}{l}{ Kelas Kontrol } \\
& \multicolumn{2}{l}{ Eksperimen } & & \\
\cline { 2 - 5 } & Pretes & Postes & Pretes & Postes \\
Nilai & 90,00 & 100,00 & 90,00 & 100,00 \\
tertinggi & & & & \\
Nilai & 45,00 & 60,00 & 25,00 & 50,00 \\
$\begin{array}{l}\text { Terendah } \\
\text { Rata-rata }\end{array}$ & 63,10 & 78,79 & 55,62 & 69,68 \\
$\begin{array}{l}\text { Standar } \\
\text { Deviasi }\end{array}$ & 12,2 & 10,74 & 14,48 & 14,53 \\
\hline
\end{tabular}

Berdasarkan tabel 7 diperoleh

nilai rata-rata pretes kelas eksperimen sebesar 63,10 dengan nilai tertinggi 90,00 dan nilai terendah 45,00 serta simpangan baku 12,2. Sedangkan untuk rata-rata nilai postes diperoleh nilai sebesar 78,79 dengan nilai tertinggi 100,00 dan nilai terendah 60,00 serta simpangan baku 10,74. Nilai rata-rata pretes kelas kontrol sebesar 55,62 dengan nilai tertinggi 90,00 dan nilai terendah 25,00 serta simpangan baku 14,48 . Sedangkan untuk rata-rata nilai postes sebesar 69,68 dengan nilai tertinggi 100,00 dan nilai terendah 50,00 serta simpangan baku sebesar 14,53 .

\section{Pembahasan}

Menurut Miarso (2011:536) indikator yang dapat digunakan untuk menentukan efektivitas dalam proses pembelajaran adalah: (a) pengorganisasian materi yang baik,

(b) komunikasi yang efektif, (c) penguasaan dan antusiasme terhadap materi pelajaran, (d) sikap positif terhadap siswa, (e) pemberian nilai yang adil, (f) keluwesan dalam pendekatan pembelajaran, dan (g) hasil belajar yang baik.

Pada penelitian ini dilakukan uji hipotesis untuk mengetahui seberapa efektif pembelajaran menggunakan media pembelajaran interaktif IPA dalam mempengaruhi hasil belajar siswa. Pengujian dilakukan dengan menggunakan uji-t dua pihak, dimana hasil belajar siswa menggunakan media pembelajaran interaktif berbasis model guided 
inquiry (inkuiri terbimbing) dikontrol dengan hasil belajar siswa yang menggunakan model guided inquiry (inkuiri terbimbing) dan buku teks.

Tabel 8. Hasil Uji t Data Postes

\begin{tabular}{llllc}
\hline Data & $\mathbf{t}$ & t table & A & Ket. \\
& hitung & & & \\
\hline Postes & 2,76 & 2,001 & 0,05 & $\begin{array}{c}\text { Ha } \\
\text { diterima }\end{array}$ \\
\hline
\end{tabular}

Berdasarkan tabel 8 dapat dilihat bahwa pada kedua kelas $t$ hitung $\geq \mathrm{t}$ tabel sehingga dapat disimpulkan bahwa terdapat perbedaan hasil

belajar antara siswa yang menggunakan media pembelajaran interaktif berbasis model guided inquiry (inkuiri terbimbing) dengan siswa yang menggunakan model guided inquiry (inkuiri terbimbing)

dan buku teks. Selain itu, juga terdapat perbedaan hasil belajar antara siswa yang menggunakan media pembelajaran interaktif berbasis model guided inquiry (inkuiri terbimbing) dengan siswa yang menggunakan model guided inquiry (inkuiri terbimbing) dan buku teks yaitu rata-rata hasil belajar siswa yang menggunakan media pembelajaran interaktif berbasis model guided inquiry (inkuiri terbimbing) sebesar 78,79 lebih tinggi dibandingkan dengan siswa yang menggunakan model guided inquiry (inkuiri terbimbing) dan buku teks yaitu sebesar 69,68.

\section{SIMPULAN}

Berdasarkan rumusan, tujuan, hasil dan pembahasan penelitian pengembangan media pembelajaran interaktif yang dikemukakan sebelumnya, maka dapat disimpulkan bahwa:

a. Hasil validasi dari ahli materi, ahli desain pembelajaran dan ahli media terhadap media pembelajaran interaktif pada pembelajaran tematik mata pelajaran IPA materi Gaya yang dikembangan dengan software Powerpoint menunjukkan bahwa keseluruhan rata-rata dikategorikan "Sangat Baik".

Setelah dilakukan beberapa revisi, media tersebut dapat digunakan untuk uji coba selanjutnya. Hasil validasi dari uji coba perorangan, uji coba kelompok kecil, dan uji coba lapangan terbatas terhadap media yang dikembangkan dengan software Powerpoint termasukdalamkategori

"Sangat Baik", sehingga dapat diterima dan layak digunakan sebagai media belajar.

b. Berdasarkan rerata hasil belajar siswa diketahui bahwa penggunaan media pembelajaran interaktif lebih efektif meningkatkan hasil belajar IPA bila dibandingkan dengan tidak menggunakan media interaktif, hal ini dapat dilihat dari nilai yang diperoleh yaitu sebesar 78,79 dan 69,68.

c. Pengujian hipotesis diperoleh thitung $>$ ttabel yaitu $2,76>2,001$ maka $\mathrm{H}_{0}$ ditolak dan sebaliknya $\mathrm{Ha}$ diterima, dimana terdapat perbedaan hasil belajar antara 
Nurul Annisa, Naeklan Simbolon: Pengembangan Media...

siswa yang menggunakan media pembelajaran interaktif berbasis model guided inquiry (inkuiri terbimbing) dengan siswa yang menggunakan model guided inquiry (inkuiri terbimbing) dan buku teks.

\section{DAFTAR RUJUKAN}

Altabany, T. I. B. 2014. Mendesain Model Pembelajaran Inovatif,

Progresif Dan Kontekstual: Konsep, Landasan dan Implementasinya Dalam Kurikulum 2013. Jakarta: Prenamedia Group.

Amri, S. 2013. Pembelajaran dan Model Dalam Kurikulum 2013. Jakarta: Prestasi Pustakaraya.

Anam, K. 2015. Pembelajaran Berbasis Inkuiri: Metode dan Aplikasi. Yogyakarta: Pustaka Pelajar.

Arief S. Sadiman, dkk. 2009. Media

Pendidikan,

Pengertian,

Pengembangan, dan

Pemanfaatannya. Jakarta:

Pustekomdikbud \& Raja Grafindo Persada.

Ariesto Hadi Sutopo. 2009. Multimedia Interaktif dengan Flash. Yogyakarta: Graha Ilmu.

Arikunto, Suharsimi. 2010. Metodelogi penelitian.

Yogyakarta: Bina Aksara.

Arsyad, Azhar. 2015. Media Pembelajaran. Jakarta:

Rajagrafindo Persada.

Asih, Widi dan Sulistyowati, Eka. 2014. Metodologi Pembelajaran IPA. Jakarta: Bumi Aksara.
Borg, W R \& Gall, M D. 2003. Educational Research: An Introduction (7.ed). New York: Longman Inc.

Cruz dela Paulo C. 2015. Development of an Experimental Science Module inquiry-based learning to Improve Middle

School Students' Integrated Science Process Skill. Proceedings of the DLSU Research Congress Vol. 3. 2015. De LaSalle University, Manila,

Philippines. Diperoleh dari www.dlsu.edu.ph/conferences/dls u_research_congress/2015/.

Diakses 14 Januari 2018. Darmawan, D. 2013. Metode Penelitian Kuantitatif. Bandung: Rosdakarya.

Dick, W \& Carey. 2015. The Systematic Design Of Instructions (Eight Edition). Boston: Herper Collin College Publisger.

Generationz.com.au. Diakses 14 Januari 2018.

Hamalik, Oemar. 2011. Perencanaan Pengajaran Berdasarkan Pendekatan Sistem. Jakarta: Bumi Aksara.

Hamdani. 2017. Strategi Belajar Mengajar. Bandung: Pustaka Setia.

Hellen Chou Pratama. 2012. Cyber Smart Parenting. Bandung: Visi Anugerah Indonesia.

Jufri, Wahab. 2013. Belajar dan Pembelajaran Sains. Bandung: Pustaka Reka Cipta.

Kemendikbud. 2014. Peraturan Menteri Pendidikan Dan Kebudayaan Republik Indonesia 
Nomor 103 Tahun 2014 Tentang

Pembelajaran Pada Pendidikan

Dasar Dan Pendidikan

Menengah. Jakarta: Menteri

Pendidikan Dan Kebudayaan

Republik Indonesia.

Kosasih. 2016. Strategi Belajar dan

Pembelajaran Implementasi

Kurikulum 2013. Bandung:

Yrama Widya.

Kurniasih, Imas dan Berlin Sani.

2017. Lebih Memahami Konsep \&

Pembelajaran Implementasi dan

Praktek Dalam Kelas. Surabaya:

Kata Pena.

Kurniasih, Imas dan Berlin Sani.

2015. Ragam Pengembangan

Model Pembelajaran Untuk

Peningkatan Profesionalitas

Guru. Surabaya: Kata Pena.

Mailiani, E. (2016). Pengembangan

Buku Ajar Geometri Dan Lembar

Aktivitas Siswa Kelas V Sds Inti

Nusantara Kota Tebing Tinggi.

Jurnal Pengabdian Kepada

Masyarakat, 20 (76).

Miarso, Yusufhadi. 2011. Menyemai

Benih Teknologi Pendidikan.

Jakarta: Kencana Prenda Media

Group.

Milovanovic, M., Obradovic, J., and Milajic, A. 2013. Application of Interactive Multimedia Tools In

Teaching Mathematics-Example Of Lesson From Geometry. TOJET: The Turkish Online

Journal of Educational Technology. Vol. 12 No.1, pp. 2930.

Murti, I. 2013. Membuat Media Mengajar Visual. Jakarta: Erlangga.
Ngalimun. 2016. Strategi dan Model Pembelajaran. Yogyakarta: Aswaja Pressindo.

Nunu Mahnun. 2012. Media Pembelajaran (Kajian terhadap Langkah-langkah Pemilihan Media dan Implementasinya dalam Pembelajaran). Jurnal Pemikiran Islam Vol. 37 No. 1 Januari-Juni 2012.

Rusman, Deni Kurniawan \& Cepi Riyana. 2012. Pembelajaran Berbasis Teknologi Informasi dan Komunikasi. Jakarta: Raja Grafindo Persada.

Samatowa, Usman. 2011. Pembelajaran IPA di Sekolah Dasar. Jakarta: Indeks.

Sanaky, Hujair AH. 2013. Media

Pembelajaran. Yogyakarta:

Safiria Insania Press.

Sanjaya, W. 2012. Media Komunikasi Pembelajaran. Jakarta: Fajar Interpratama Mandiri.

Simbolon, N. 2017. Project Based Learning Implementation To Enable Students'activities. School Education Journal PGSD FIP UNIMED, 4(2), 1-8.

Sugiyono. 2016. Metode Penelitian Pendidikan. Bandung: Alfabeta.

Trianto. 2013. Model Pembelajaran Terpadu. Jakarta: Bumi Aksara. Wijaya, A M dkk. 2017. Digital

Media Based on Macromedia Flash to Increase the Historical LearningInterest of Senior High

School Students. American International Journal of Social Science. Vol. 6, No. 2, June 2017, pp. 71-77. 